\title{
The Effect of Sales Promotion and Knowledge on Impulsive Buying of Online Platform Consumers
}

\author{
Tasneem Al Mutanafisa ${ }^{* 1}$, Retnaningsih ${ }^{2}$ \\ ${ }^{1}$ Department of Family and Consumer Sciences, Faculty of Human Ecology, IPB \\ University, Bogor 16680, Indonesia \\ ${ }^{2}$ School of Business IPB University, Bogor, Indonesia \\ *Corresponding author: tasneemalmutanafisa@gmail.com
}

\begin{abstract}
Impulsive buying is an unplanned purchase decision due to stimulation from the shopping environment. This study aims to analyze the consumer characteristics and sales promotion, knowledge, and impulsive buying and the influence of consumer characteristics, sales promotion, and knowledge on impulsive buying. The study used a cross-sectional study design, which was conducted from December 2019 to January 2020. In this study, respondents were 145 Shopee users who made purchases in the last three months selected purposively. Data were collected by filling out an online questionnaire. The results showed that the length of education was related to sales promotion and knowledge, while income and promotion were related to impulsive buying. Meanwhile, a factor that has a positive effect on impulsive buying is sales promotion. Unplanned online purchases are most often made in the middle of the month, and promotions are the most influential in purchasing decisions.
\end{abstract}

Keywords: impulsive online buying, knowledge, sales promotion, the online platform

\begin{abstract}
Abstrak
Implusive buying salah satu keputusan pembelian yang tidak terencana karena adanya rangsangan dari lingkungan belanja. Penelitian ini bertujuan untuk menganalisis pengaruh karakteristik konsumen dengan promosi penjualan, pengetahuan, dan impulsive buying serta pengaruh karakteristik konsumen, promosi penjualan, dan pengetahuan, terhadap impulsive buying. Penelitian menggunakan desain cross sectional study yang dilakukan dari bulan Desember 2019 sampai Januari 2020. Responden dalam penelitian ini adalah 145 pengguna Shopee yang melakukan pembelian dalam tiga bulan terakhir yang dipilih secara purposive. Data dikumpulkan melalui pengisian kuisioner secara online. Hasil penelitian menunjukkan bahwa lama pendidikan berhubungan dengan promosi penjualan dan pengetahuan, sedangkan pendapatan dan promosi berhubungan dengan impulsive buying. Faktor yang berpengaruh positif terhadap impulsive buying adalah promosi penjualan. Pembelian online yang tidak direncanakan paling sering dilakukan pada pertengahan bulan, dan promosi menjadi faktor yang paling mempengaruhi keputusan pembelian.
\end{abstract}

Kata kunci: impulsive buying, pengetahuan, platform online, promosi penjualan 


\section{Introduction}

The development of information and communication technology, especially the internet, has changed consumer behavior offline, namely meeting directly between sellers and buyers, online, that is, without meeting directly between sellers and buyers. Based on a report released by We Are Social (2017), the percentage of online purchases of Indonesians' goods and services has increased dramatically, from only $26 \%$ in 2016 to $41 \%$ in 2017 of the entire population. This shows that Indonesians have a high interest in online shopping.

Through the internet makes it easier for consumers to make purchases online. Besides, the growth of e-commerce in Indonesia is increasingly making people's consumptive behavior also increase (Ika, Fitriyah, \& Dewi, 2020). Based on data found on the iPrice (2020) page, currently, the Shopee platform as the most popular ecommerce online shopping application is used based on Android and iOS. Thus can be seen from the many consumers' interest in visiting the Shopee page, making impulse buying possible.

Rook (1987) defines impulse buying as consumers who suddenly experience a strong enough urge and will continue to buy something as soon as possible. Impulse buying often referred to as unplanned purchases. According to Ummah and Rahayu (2020), the impulse buying phenomenon in Indonesia is relatively high (50\%), thus can see based on data from $\mathrm{CNN}$, that the millennial generation is the most impulsive customer in the Asia Pacific and also followed by Thailand (60\%). This is consistent with what Rook and Fisher (1995) said that impulsive buying could be online.

According to Wijaya and Oktarina (2019), the right marketing strategy requires marketers to know their consumers more because consumer wants and needs can continue to change. One of the factors that trigger impulsive purchases is a sales promotion. Sales promotion is defined as an activity that aims to urge specific target market segments to buy a product, such as giving discounts or offering gifts when buying a product. The primary purpose of sales promotion is to stimulate potential customers to purchase the products offered (Kiran, Vasanth, Majumdar, \& Kishore, 2012). This shows that promotions and special offers when opening the Shopee application affect buyers who make impulsive buying (Wahyuni \& Setyawati, 2020). Bhakat (2013) explains that promotion is one of the factors that affect impulsive buying. The number of promotions offered in these marketplaces can encourage consumers to make purchases outside the plan, resulting in impulsive buying.

Also, other factors that can influence impulse buying are knowledge, such as product knowledge. Anisa, Seojoto support this, and Harti (2017) that product knowledge is related to impulse buying, where impulse buying will increase when consumers know and understand about a product being purchased. This shows that the higher the consumer's knowledge of a product, the more impulse buying will occur (Liang, 2012). In this regard, Peter and Olson (2000) explain that consumers have different knowledge levels, using it to translate new information and make purchase choices.

Unplanned purchases, one of which in e-commerce, occur a lot because they are supported by stimuli such as promotions, purchase guarantees, and convenience (Wulan, Suharyati, \& Rosali, 2019). The Shopee online platform with the highest number of active users is due to this application because it has an attractive appearance and is easy to use. Supported by Wulan et al. (2019) research results, Shopee has 
provided features that are comfortable to use, attractive, and make it easier for customers to shop online to trigger impulsive buying. In line with Mark's research results plus the 2020 range of offers and the convenience of the online shopping experience, Shopee became a major platform and a strategy to strengthen businesses in the digital realm or online.

Based on the above phenomenon, previous studies supported that unplanned purchases can be driven by the promotion of sales and product knowledge. This makes researchers interested in conducting research aimed at 1) Identifying consumer buying behavior on online platforms in general; 2) Identifying product knowledge and impulsive buying behavior on online platform consumers; 3) Analyze the relationship between consumer characteristics, sales promotion, product knowledge, and impulsive buying behavior on online platform consumers; and 4) Analyze the influence of consumer characteristics, sales promotion, and product knowledge of the behavior of the consumer impulsive buying online platform.

\section{Literature Review}

\section{Sales Promotion}

According to Kotler and Armstrong (2014), the definition of sales promotion is a short-term incentive to encourage the desire and to try or buy a product or service. The importance of sales promotion is now increasingly being recognized, especially in very tight market competition. Although the sales promotion tools vary, the sales promotion tools have their characteristics. According to Kotler and Armstrong (2012), indicators of sales promotion are the performance of the samples, coupons, cash refund, special rates/price reductions, premiums, particular goods advertising/sales promotion products, award support, and sales promotion point of sale, contests, sweepstakes, and games.

According to (Leba, 2015), stores with good sales promotion programs will find it easier to realize impulse buying for consumers than stores that do not have effective sales promotion programs. The study of Zhang, Jing, and Yang (2012) confirm that someone will be more impulsive to buy online products because of promotions in vouchers and satisfaction that cannot be fulfilled immediately. The consumer's impulsive buying is more of a hedonic behavior than buying utilitarian necessities (e.g., rice). Besides, price is also one of the main factors for someone who has a positive effect to explore and encourage impulsive purchases (Park, Kim, Funches, \& Foxx, 2012).

\section{Knowledge}

Consumer knowledge is often called "product-related knowledge," namely, the knowledge that shows the level of experience, expertise, and familiarity consumers have with a product. Consumer knowledge refers to internalized information that consumers use when making decisions (Kolyesnikova, Lavarie, Duhan, Wilcox, \& Dodd, 2010). Consumer knowledge is a multidimensional concept consisting of experience, expertise, and familiarity (Ateke, Walter, \& Didia, 2018). Sumarwan (2011) stated that factors that can affect a person's knowledge include age, gender, education, occupation, income, family size, and geographic location.

When making purchases, consumers often rely on personal memory or experience to make decisions. According to Beatty and Smith (1987), product knowledge is the 
perception that consumers have of a particular product, including previous experience using the product. Consumers who have more product knowledge will encourage impulsive buying behavior because they are more familiar with product quality than consumers with less product knowledge (Mahadewi \& Sulistyawati, 2019). The results of studies reinforce this by Liang (2012), Deviana and Giantari (2016) that consumer product knowledge affects impulse buying.

\section{Impulsive Buying}

According to Schiffman and Kanuk (2007), the definition of impulse buying is a strong emotional decision and can be the basis for the dominant unplanned purchase motive. Bhakat (2013) explains that four factors influence impulsive purchases, namely internal factors, external factors, shopping channel factors, store characteristics, perceived crowding, and peer and family presence. Situation factors include time available and money available. Meanwhile, demographic factors include gender, age, education, and income.

The study of Bashar, Ahmad, and Wasiq (2013) as well as Amos, Holmes, and Keneson (2014) reinforced that demographic factors, namely income, can affect impulsive buying. According to Rook (1987) and Greenfield (1999), in the late 1980s, impulsive buying became easy because of innovations such as credit cards, and selecting a product by simply "clicking" on the product created an impulse that could increase impulsive buying. Besides, Verplanken and Herabadi (2001) in their study suggest that there are two aspects of impulse buying :

a) Cognitive aspects: This is related to the consideration and planning of purchases. Described that the payment includes conditions that are not planned or there is careful consideration for various reasons so that it will cause a repetition of the same thing in the payment situation.

b) Affective aspect: This is related to the emotional impulse, which includes feeling happy and happy after purchasing without planning. This behavior arises based on the heart's desire and its nature repeated, uncontrollable, and satisfaction, or regret.

Other factors that can encourage impulse buying are the marketing environment (display and product offerings, availability of time and space, mood, self-identity, personality, and education (Verplanken \& Herabadi, 2001). Based on previous empirical research that has been previously described, it has been found that there is a relationship between sales promotion variables, knowledge, and impulsive buying behavior. Through this research, these variables will be compared to consumers who make online purchases at Shopee. Sumarwan (2011) states that factors that can affect a person's knowledge include age, gender, education, occupation, income, family size, and geographic location. The description above can describe the framework of sales promotion, knowledge, and Impulsive buying as presented in Figure 1. 


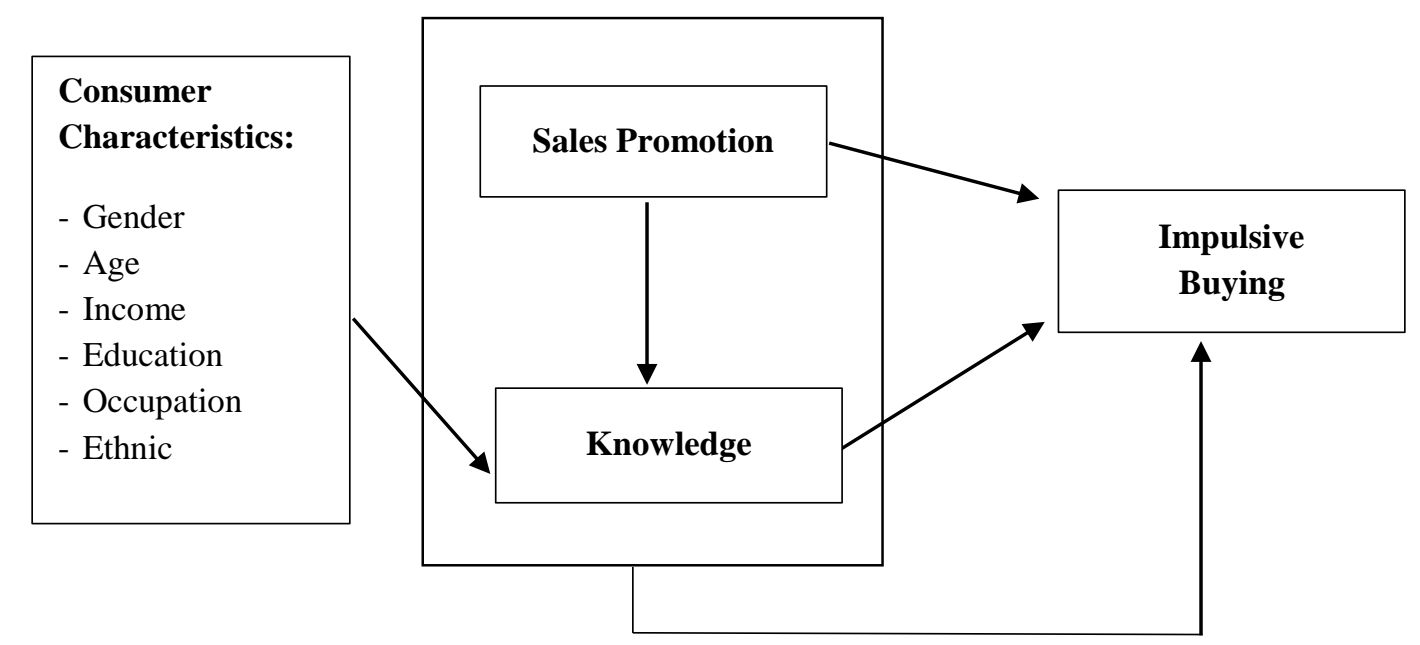

Figure 1. Theoretical framework

The hyphotesis research of this study can be concluded as follows:

H1: Consumer characteristics significantly affect the consumer knowledge

H2: Sales promotion significantly affect the consumer knowledge

H3: Sales promotion significantly affect the impulse buying.

H4: Product knowledge significantly affect the impulse buying.

H5: Sales promotion and product knowledge significantly affect the impulse buying together.

\section{Methods}

\section{Participants}

This study used a cross-sectional study design using online questionnaire filling techniques for Shopee users in Indonesia. Data collection was carried out from December 2019 to January 2020. The population includes an unidentified number of Shopee users in Indonesia. The sampling technique used in this study is nonprobability sampling using the purposive sampling method. The population elements were selected based on specific criteria set by the researcher. The criteria used for sampling include a Shopee user in Indonesia who purchased in the last three months. The number of samples taken was 145 online platform consumers who filled out online questionnaires, and henceforth, the term Shopee online platform consumers will be called online consumers.

\section{Measurement}

Sales promotion is an incentive that Shopee does to attract consumers, including discounts, coupons, and raffle and game contests. The questionnaire used to measure sales promotions was adapted from a questionnaire made by Clara (2017) and modified according to the researcher's needs by adjusting the topic, language, and sales promotion dimensions under study, namely the dimensions of discount, coupons, and lottery and game contests. The questionnaire contains 15 statement with answer choices $1=$ strongly disagree $; 2=$ disagree $; 3=$ simply agree; $4=$ agree , and $5=$ strongly agree . 
Knowledge is information that someone has about Shopee and is measured based on consumer knowledge theory (Sumarwan, 2011). The knowledge questionnaire was adapted based on the questionnaire developed by Putri (2017) according to consumer knowledge dimensions, including product knowledge, product acquisition knowledge, and useful knowledge. The number of statements is 16 items with a choice of answer choices $0=$ wrong; $1=$ right.

Impulsive buying is buying behavior spontaneously without being planned or suddenly when shopping online. The impulsive buying questionnaire adapted from a questionnaire developed by Am (2019) was modified according to the indicators of impulsive buying according to Bayley and Nancarrow (1998), which included spontaneous purchases, thoughtless purchases of consequences, rushed purchases, and emotional states influenced purchases. The number of statements is 8 items with a choice of answer choices $1=$ strongly disagree; $2=$ disagree; $3=$ simply agree; $4=$ agree; and $5=$ strongly agree.

\section{Analysis}

Data analysis processing performed using the SPSS 25.0 for Windows program. The analysis carried out was descriptive analysis (mean, standard deviation, minimum value, and maximum value), correlation analysis, and linear regression analysis.

\section{Findings}

\section{Respondent Characteristics}

The age of online consumers in this study ranged from 17-51 years. Most of the respondents $(62.1 \%)$ studied up to the university level with a duration of 13-16 years. As many as 58.6 percent of online consumers in this study worked while the rest (41.4\%) did not work (students and housewives). Respondents' monthly income ranges from Rp. 0, - up to Rp. 30,000,000.- with an average income of Rp. 3,868,688.

There is 58.6 percent of online consumers who work, while 41.4 percent do not work, which means that they do not have a job or have a job status but do not generate income, such as students and housewives. Most of the online consumers work as private employees $(33.1 \%)$. The lowest income is zero because some online consumers who do not have a job and are housewives answered that they have no income. As many as 40.7 percent of online consumers come from Javanese ethnicity; Sundanese is the second largest ethnic group (29.7\%).

\section{Purchasing Behavior}

This study indicates that online consumer purchases at Shopee in one month range from 1 to 25 times. The result is that the frequency of online consumer purchases at Shopee in this study is categorized as low 1 to 8 times a month. Sometimes $(50.3 \%)$ of these online consumers have purchase planning habits, including planning purchases at Shopee $(59.3 \%)$.

Unplanned purchases were mostly made in the middle of the month $(58.6 \%)$. One of the factors is the existence of sales promotions (42.8\%) which influence online consumer purchasing decisions, followed by self-desire (36.6\%), the media (11\%), and other people $(9.7 \%)$. The price aspect $(68.3 \%)$ was also able to influence purchasing decisions, followed by brand consideration (14.5\%). This indicates that sales 
promotions and prices on the Shopee platform can affect consumer purchasing decisions unplanned.

Table 1 Distribution of samples based on item categories on Shopee

\begin{tabular}{lccc}
\hline Item Category & $\begin{array}{c}\text { Items that most } \\
\text { frequently } \\
\text { purchased at Shopee } \\
\text { \% }\end{array}$ & $\begin{array}{c}\text { Items that usually } \\
\text { bought at Shopee } \\
\text { without planning }\end{array}$ & $\begin{array}{c}\text { Items usually } \\
\text { purchased at Shopee } \\
\text { with prior planning }\end{array}$ \\
\hline Fashion & 43.4 & 29.0 & 34.5 \\
Beauty product & 23.4 & 15.9 & 22.1 \\
Electronic/Gadget & 13.1 & 7.6 & 15.2 \\
Household Products & 10.3 & 4.8 & 13.1 \\
Baby / Child & 12.4 & 5.5 & 10.3 \\
Equipment & & & \\
Health Products & 3.4 & 2.1 & 2.8 \\
Books \& Stationery & 3.4 & 2.8 & 4.8 \\
Hobbies \& & 2.1 & 4.1 & 1.4 \\
Collections & & & \\
Food \& Beverage & 3.4 & 0.7 & 4.1 \\
Others & 17.2 & 20.7 & 16.6 \\
\hline
\end{tabular}

The results in Table 1 show that most Shopee users and online research consumers are female. Fashion and beauty products rank the two highest in the types of stuff online consumers buy at Shopee, namely at 43.4 percent and 23.4 percent. Fashion ranks highest as the most purchased item at Shopee without planning $(29 \%)$ or prior planning $(34.5 \%)$. Apart from fashion and beauty products, electronics are often purchased with prior planning $(15.2 \%)$.

\section{Sales Promotion}

In this study, three types of sales promotions were studied: discounts, vouchers, and games. Online consumer responses to each sale are categorized into four categories: deficient, low, high, and very high (Table 2). The deficient category indicates that this type of sales promotion has almost no traction for online consumers. Meanwhile, the high category shows the high attractiveness of online consumers' sales promotion to trigger purchases of Shopee.

Table 2 Distribution of respondents based on sales promotions

\begin{tabular}{llrr}
\hline Sales Promotion & & n & \% \\
\hline Discount/Potongan Harga/Flash Sale & Very low & 8 & 5.5 \\
& Low & 35 & 24.1 \\
& High & 57 & 39.3 \\
Coupons/Voucher & Very High & 45 & 31.0 \\
& Very low & 20 & 13.8 \\
& Low & 35 & 24.1 \\
Sweepstakes and Games Contests (games) & High & 55 & 37.9 \\
& Very High & 35 & 24.1 \\
& & & 61.4 \\
\hline
\end{tabular}




\begin{tabular}{llrr}
\hline Sales Promotion & & n & \multicolumn{1}{c}{$\%$} \\
\hline & High & 11 & 7.6 \\
& Very High & 2 & 1.4 \\
\hline Total & & 145 & 100 \\
\hline
\end{tabular}

The results in Table 2 show that the sales promotion that most increases the desire of online consumers to purchase goods at Shopee is a discount/flash sale. This can be seen from the number of online consumers who agree that the discount is in the high category $(39.3 \%)$ and very high $(31 \%)$. In the form of coupons, sales promotion is in the second position to increase the desire to buy at Shopee with 37.9 percent in the high category and 24.1 percent in the very high category. Meanwhile, sales promotion in sweepstakes and games contests is almost very low (61.4\%) in encouraging online consumers to purchase at Shopee.

\section{Knowledge}

The knowledge researched in this study is consumer knowledge about Shopee, which includes product knowledge, product acquisition knowledge, and useful knowledge. The distribution in Table 3 shows that the category of online consumer knowledge level shows that most of the consumer's knowledge in the three aspects is high-usage knowledge, which has the lowest high percentage of online consumers $(65.5 \%)$ other two aspects. This shows that many online consumers do not know well about how to use and general things about Shopee.

Table 3 Distribution of respondents based on knowledge

\begin{tabular}{llrr}
\hline Knowledge & & $\mathbf{n}$ & $\mathbf{\%}$ \\
\hline Product knowledge & Low & 2 & 1.4 \\
& Moderate & 9 & 6.2 \\
Product acquisition knowledge & High & 134 & 92.4 \\
& Low & 1 & 0.7 \\
& Moderate & 12 & 8.3 \\
Usage Knowledge & High & 132 & 91.0 \\
& Low & 19 & 13.1 \\
& Moderate & 31 & 21.4 \\
& High & 95 & 65.5 \\
\hline Total & & 145 & 100 \\
\hline
\end{tabular}

\section{Impulsive Buying}

The distribution results in Table 4 show that most of the online consumers (51\%) are in the low category with impulsive buying behavior. This shows that most online consumers rarely make online purchases without prior planning at Shopee. Meanwhile, as many as 15.9 percent of online consumers are still high in unplanned purchases on the Shopee platform. 
Table 4 Distribution of respondents based on impulsive buying

\begin{tabular}{llrr}
\hline Variable & & n & \% \\
\hline Impulsive buying & Very low & 47 & 32.4 \\
& Low & 74 & 51.0 \\
& High & 23 & 15,9 \\
& Very high & 1 & 0,7 \\
\hline Total & & 145 & 100 \\
\hline
\end{tabular}

Correlation between Consumer Characteristics, Sales Promotion, Product Knowledge and Online Impulsive Buying Behavior

The Spearman correlation analysis results in Table 5 show a significant negative relationship in the variable length of education and promotion. This means that the higher a person's education, the lower the promotion's contribution in triggering the desire to buy stuff. Meanwhile, the length of education shows a positive relationship to knowledge, which means that the higher the education a person takes, the higher their knowledge.

Table 5 Correlation test of consumer characteristics, promotion, and knowledge, with impulsive buying

\begin{tabular}{lccc}
\hline Variables & Sales Promotion & Knowledge & Impulsive buying \\
\hline Age & -0.073 & -0.003 & -0.023 \\
Education & $-0.208^{*}$ & $0.257^{* *}$ & -0.105 \\
Monthly income & -0.107 & 0.066 & $0.180^{*}$ \\
Sales promotion & 1.000 & 0.078 & $0.222^{* *}$ \\
Knowledge & & 1.000 & 0.049 \\
Impulsive buying & & & 1.000 \\
\hline
\end{tabular}

Note: $(* *)$ significant at $\mathrm{p}<0.01 ;(*)$ significant at $\mathrm{p}<0.05$

The correlation analysis results in Table 5 show that there is a significant negative relationship between education and sales promotion. This means that the higher a person's education, the lower the promotion's contribution in triggering the desire to buy stuff. Meanwhile, the length of education shows a positive relationship to knowledge, which means that the higher the education a person takes, the higher their knowledge.

Other results indicate that there is a significant positive relationship between income and impulsive buying behavior. This means that the higher the monthly income received by consumers, the higher the impulsive buying behavior. Also, there is a significant positive relationship between sales promotion and impulsive buying. This means that the more sales promotions consumers get, the higher the tendency for consumers to make impulsive buying online. Meanwhile, other results show that the length of education is closely related to knowledge. It means that the higher the education of consumers, the knowledge of a product will also increase.

The Influence of Consumer Characteristics, Sales Promotion, and Product Knowledge on Online Impulse Buying Behavior

Table 6 shows that the model generated from the linear regression test has an Adjusted R-Square value of 0.087 , or the independent variable studied is 8.7 percent 
affecting impulsive buying. The remaining 91.3 percent influenced by other variables that are not studied.

Table 6 The influence of consumer characteristics, sales promotion, and product knowledge

\begin{tabular}{lcc}
\hline \multirow{2}{*}{ Variables } & \multicolumn{3}{c}{ Impulsive buying } \\
\cline { 2 - 3 } & $\beta$ & Sig. \\
\hline Gender & -1.188 & 0.269 \\
Age & -1.513 & 0.219 \\
Education & -0.253 & 0.342 \\
Occupation & 1.049 & 0.271 \\
Income & 0.490 & 0.207 \\
Ethnic & 0.136 & 0.875 \\
Sales promotion & 0.146 & $0.001^{*}$ \\
Knowledge & 0.025 & 0.932 \\
\hline Df & & 8.712 \\
$\mathrm{~F}$ & & 0.371 \\
$\mathrm{R}$ & & 0.087 \\
Adj R Square & & $0.008^{*}$ \\
Sig. & & 145 \\
$\mathrm{~N}$ & &
\end{tabular}

The analysis results in Table 6 show that sales promotions affect impulsive buying $(\beta=0.146)$. This means that the more promotions consumers receive, the higher the unplanned purchases made by consumers. Meanwhile, there was no significant effect on impulse buying by other variables.

\section{Discussion}

In this study, as many as 80 percent of these consumers were female. This figure shows that the number of female Shopee users is higher than male Shopee users. According to Latifah, Widayani, and Normawati (2020), Shopee e-commerce users are more women than male users. This is because women prefer to shop than men. This unbalanced gender difference in the number of online consumers can also cause the not finding a relationship between gender and impulsive buying in the study results. In the distribution of consumer behavior, fashion and beauty products are categories of goods that occupy the first and second positions, both in goods that are often purchased with planning or without prior planning. This can be caused by the large number of female consumers who become online consumers so that fashion is ranked first in both. The distribution results show that impulsive buying is more often done in the middle of the month. The higher intensity of promotions carried out by marketers in the middle of the month is likely to be the leading cause of this phenomenon.

The current pandemic has forced most people to do more activities at home so that online transactions have become an increasingly popular alternative. Gadgets and the internet are the tools most widely used by people today, especially for entertainment or shopping while at home. This will increase the likelihood of consumers' exposure to the various kinds of promotions they encounter from existing media, thereby increasing impulsive buying behavior. This is also supported by the correlation test results, which indicate a significant positive relationship between sales promotion variables and 
impulsive buying. It is in line with studies conducted by Yang, Huang, and Feng (2011) that there is a positive correlation between promotion and the desire to do impulsive buying.

Besides, the length of education is also related to sales promotion in this study. A study by Yang, Huang, and Feng (2011) stated a significant difference between promoting promotion on high school students (SMA) and university students, where students are more likely to be affected by promotion than high school students. This is different from the results of this study which state that the higher a person's education level, the lower the sales promotion. Meanwhile, the length of education shows a significant positive relationship to knowledge. According to Fazrina, Marsaulina, and Naria (2013), education can influence consumers to choose the desired product because a person's education level will affect their values, ways of thinking, point of view, and even knowledge perceptions of a product that is consumed. A significant positive relationship also occurs in the variable income or monthly allowance with impulsive buying behavior. These results are consistent with Rana and Tirthani's (2012) research, which found a relationship between income and impulsive buying. Consumers with high incomes will be more impulsive in their purchasing decisions than consumers with less income. This is because someone who has an excellent financial condition is low in considering and thinking about the consequences of making purchases that are not needed. Rook's theory in Cahyorini and Rusfian (2012) states that one of the characteristics of impulsive buying is ignoring the negative consequences that may occur due to impulsive buying.

Based on this, someone's knowledge also plays a role in decision making to carry out impulse buying behavior and, of course, supported by the research results that the influence of knowledge on impulsive buying. Reinforced by the theory in Sumarwan (2011), which states that consumer knowledge of the product will increase the ability to choose the product to be purchased, cannot prove it in the research results. This happens because even though consumers have good knowledge, other factors such as intense promotions can be a stimulus to encourage consumer emotions to continue to do impulsive buying. According to Bayley and Nancarrow (1998), impulsive buying is a purchase that is influenced by an emotional state.

Other results also show that the promotion variable has a significant positive effect on impulsive buying behavior online. This is in line with Rondonuwu's (2013) research, which states that promotion positively affects purchasing decisions. The test results are also following the research of Nindyakirana and Maftukhah (2016), which states that sales promotions directly affect impulsive buying, where the higher the sales promotion is applied, it can increase impulse buying. However, this result is different from the research results by Rosyida and Anjarwati (2016), which state that promotion has a positive but not significant effect on impulsive buying. The difference in these results can be due to differences in the sex of online consumers studied. Rosyida and Anjarwati (2016) only took a sample of female consumers, while this study was conducted by taking samples of female and male consumers.

The strong influence of sales promotion on impulsive buying behavior makes it essential for a consumer to know the seller's promotional tips to avoid buying just because of a moment's desire. Consumers must be more careful in processing information from promotion and ensuring that the promotion is profitable or just a marketer's trick. The form of promotion that will have a more significant influence on consumer impulse buying is a promotion that has a short time limit. Bayley and 
Nancarrow (1998) say that rush buying is an indicator of impulsive buying behavior. The promotion carried out with a limited time will reduce consumers' opportunity to consider the goods they will buy and encourage consumers to make a rushed purchase. This study has limitations: it does not differentiate between online consumers shopping as a reseller and themselves. Therefore, further research is expected to improve the weaknesses in this study.

\section{Conclusion and Recommendation}

\section{Conclusion}

The frequency of purchases online is mostly made between one and eight times a month. Online purchases are relatively unplanned, and most online consumers make a purchase plan on occasion. Unplanned online purchases are most often made in the middle of the month. Sales promotion is the thing that most influences purchasing decisions. Meanwhile, price is the aspect that most influences purchasing decisions. Fashion is the category of goods that consumers buy most online.

Discount or flash sale is a type of promotion that is most in demand by online consumers. Meanwhile, games are the least popular type of promotion. The knowledge of online consumers is high, and product knowledge is the most mastered by consumers. The level of impulsive buying online consumers is low. The relationship test shows that there is a significant negative relationship between the length of education and promotion. The length of education shows a significant positive relationship with knowledge. Income, allowance, and sales promotion also have a significant positive relationship with impulsive buying. Meanwhile, the influence test results show that only sales promotions affect the impulsive buying behavior of online consumers.

\section{Recommendation}

Consumers are starting to make plans before making purchases online and offline to avoid impulsive buying behavior. Making a purchase plan can resist impulsive buying of unnecessary items when faced with various promotions. Especially in the new normal situation after the outbreak of the COVID 19 outbreak, most people spend more of their time on devices, so they are exposed to more promotions and make more transactions online. Seeing the current conditions, the possible socialization to be carried out is through social media because most people nowadays have easy access to the internet.

\section{References}

Am Ro'is, M. (2019). Studi Komparasi Nilai, Kontrol Diri, Sikap Dan Pembelian Impulsif Antargenerasi. [Skripsi]. Bogor: Institut Pertanian Bogor.

Amos, C., Holmes, G. R., \& Keneson, W. C. (2014). A meta-analysis of consumer impulse buying. Journal of Retailing and Consumer Services, 21, 86-97. http://dx.doi.org/10.1016/j.jretconser.2013.11.004

Ateke, B, Walter, \& Didia, J.U.D. (2018). Consumer knowledge and purchase intention of healthcare product consumers in rivers state. International Journal of Business \& Law Research. 6(1):1-7 
Bashar, A., Ahmad, I., \& Wasiq, M. (2013). A study of the influence of demographic factors on consumer impulse buying behavior. Journal of Management Research, 13(3), 145-154. http://dx.doi.org/10.1086/209186

Bayley, G., \& Nancarrow, C. (1998). Impulse purchasing: a qualitative exploration of the phenomenon. Qualitative Market Research, 1(2), 99-114. Doi: https://doi.org/10.1108/13522759810214271.

Beatty, S. E., \& Smith, S. M. (1987). External search effort: An investigation across several product categories. Journal of consumer research, 14(1), 83-95.

Cahyorini, A, \& Rusfian, E.Z. (2012). The effect of packaging design on impulsive buying. Bisnis dan Birokrasi Journal. 18(1).

Clara, M. (2017). Pengaruh Promosi Penjualan Terhadap Keputusan Pembelian Impulsif Ibu Rumah Tangga (Studi Kasus Department Store Di Kota Bogor). [Skripsi]. Bogor (ID): Institut Pertanian Bogor.

Deviana, N. P. S., \& Giantari, I. G. A. K. (2016). Pengaruh Shopping Lifestyle dan Fashion Involvement terhadap Impulse Buying Behavior Masyrakat di Kota Denpasar. E-Jurnal Manajemen Universitas Udayana, 5(8), 5264- 5273.

Fazrina, R., Marsaulina, I., \& Naria, E. (2013). Hubungan karakteristik dan pengetahuan tentang lingkungan sehat dengan keputusan konsumen dalam membeli sayuran organik di Carrefour Plaza Medan Fair. Jurnal Program Sarjana Fakultas Kesehatan Masyarakat Universitas Sumatera Utara. Retrieved from: https://jurnal.usu.ac.id/index.php/lkk/article/view/3271/1597

Greenfield, D.N. (1999). Psychological characteristics of compulsive internet use: a preliminary analysis. Cyberpsychology \& Behavior, 2(5), 403-412

Hootsuite, We Are Social. (2017). Digital in 2017: Southeast Asia. Hootsuite \& We Are Social.

Ika, N., Fitriyah, Z., \& Dewi, N.C. (2020). Impluse buying di e-commerce Shopee. Dinamika Administrasi: Jurnal Ilmu Administrasi dan Manajemen, 3(1), 57-62.

iPrice. (November, 2020). Mapofecommerce. Retrieved from: https://iprice.co.id/insights/mapofecommerce/

Kiran, Vasanth, Majumdar, M, \& Kishore, K. (2012). Innovation in in-store promotion: Effects on consumer purchase decision. European Journal of Business and Management. 4(9):36-44.

Kolyesnikova, N., Laverie, D. A., Duhan, D. F., Wilcox, J. B., \& Dodd, T. H. (2010). The influence of product knowledge on purchase venue choice: Does knowing more lead from bricks to clicks?. Supply Chain Forum: An International Journal, 11(1), 28-40.

Kotler, P, \& Amstrong, G. (2012). Principles of Marketing. Ed ke-15th. New Jersey (US): Pearson Education Limited.

Kotler, P., \& Amstrong, G. (2014). Principles of Marketing. Ed ke-12. Jilid 1. Jakarta (ID): Erlangga.

Kusumawardhani, A. (September, 2020). Survei MarkPlus, Inc: Shopee kuasai peta persaingan e-commerce. Retrieved from: https://ekonomi.bisnis.com/read/20200917/12/1293028/survei-markplus-incshopee-kuasai-peta-persaingan-e-commerce

Latifah, N., Widayani, A., \& Normawati, R.A. (2020). Pengaruh perceived usefulness dan trust terhadap kepuasan konsumen pada e-commerce Shopee. Bisma: Jurnal Bisnis dan Manajemen. 14(1):82-91. p-ISSN 1978-3108, e-ISSN 2623-0879.

Leba, E.E. (2015). Women issues in Hillary Clinton's speeches. Rubikon: Journal of 
Transnational American Studies. 2(2):24-40.

Liang, YP. (2012). The relationship between consumer product involvement; product knowledge and impulsive buying behaviour. Procedia - Social and Behavioral Science, 57, 325-330. Doi :10.1016/j.sbspro.2012.09.1193.

Mahadewi, N.P.T., \& Sulistyawati, E. (2019). Peran positive emotion dalam memidasi pengaruh product knowledge terhadap impulse buying. E-Jurnal Manajemen, 8(9), 5652-5671. DOI: https://doi.org/10.24843/EJMUNUD.2019.v08.i09.p15

Nindyakirana, R.H, \& Maftukhah, I. (2016). Membangun emosi positif melalui promosi penjualan dan lingkungan toko dampaknya terhadap impulse buying. Management Analysis Journal. 4(1):375-388.

Park, E.J., Kim e.Y., Funches, V.M., \& Foxx, W. (2012). Apparel product attributes, web browsing, and e-impulse buying on shopping websites. Journal of Business Research, 65(11), 1583-1589.

Peter, J. P., \& Olson, J. C. (2000). Consumer Behavior: Perilaku Konsumen dan Strategi Pemasaran. Jakarta(ID: Erlangga

Putri, R.A.A. (2017). Analisis Paparan Video Impulsive buying Terhadap Pengetahuan, Gaya Hidup, Dan Intensi Menurunkan Perilaku Impulsive buying. [Skripsi]. Bogor (ID): Institut Pertanian Bogor.

Rana, S., \& Tirthani, J. (2012). Effect of education, income and gender on impulsive buying among Indian consumer an empirical study of readymade garment customers. Indian Journal of Applied Research. 1(12):145-146.

Rondonuwu, M. (2013). Tingkat pendidikan, motivasi dan promosi pengaruhnya terhadap keputusan penggunaan produk nasabah priority banking Bank Sulut. Jurnal EMBA. 1(3): 257-264. ISSN 2303-1174.

Rook, D.W. (1987). The buying impulse. Journal of Consumer Research, 14(2), 189199. Doi: https://doi.org/10.1086/209105.

Rook, D.W., \& Fisher, R.J. (1995). Normative influence on impulse buying behavior. Journal of Consumer Research, 22(3), 305-313. Doi: https://doi.org/10.1086/209452

Rosyida, S,. \& Anjarwati, A.L. (2016). Pengaruh store atmosfer dan promosi penjualan terhadap pembelian impulsif dengan emosi positif sebagai variabel intervening. Journal of Research in Economics and Management Jurnal Riset Ekonomi dan Manajemen. 16(1):105-127.

Schiffman, Leon G. Leslie Lazar Kanuk. (2007). "Consumer Behavior". NY: Pearson Prentice Hall

Sumarwan, U. (2011). Perilaku Konsumen: Teori dan Penerapannya dalam Pemasaran. Bogor (ID): Ghalia Indonesia.

Ummah, N.M., \& Rahayu, S.A. (2020). Fashion involvement, shopping lifestyle, dan pembelian implusif produk fashion. Jurnal Penelitian Psikologi, 11(1), 33-40. Doi: http://doi.org/10.29080/jpp.v11i1.350

Wijaya, E., \& Oktarina, Y. (2019). Faktror-faktor yang mempengaruhi impulse buying pada Hodshop Bengkulu. Ekombis Review: Jurnal Ekonomi dan Bisnis, 7(1), 1022. Doi: https://doi.org/10.37676/ekombis.v7i1.696

Wulan, W.N.N., Suharyati, \& Rosali. (2019). Analisis pembelian tidak terencana pada toko online shopee. Jurnal Ekonomi dan Bisnis, 6(1), 54-71. Doi: 10.35590/jeb.v6i1.830

Yang, D.J., Huang, K.C., \& Feng, X. (2011). A study of the factors that affect the impulsive cosmetics buying of female consumers in Kaohsiung. International 
Journal of Business and Social Science. 2(24):275-282.

Yistiani, Manik, N.N., Yasa, N.N.K., \& Suasana, I.G.A.K.G. (2012). Pengaruh atmosfer gerai dan pelayanan ritel terhadap nilai hedonik dan pembelian impulsif pelanggan matahari department store duta plaza di Denpasar. Jurnal Manajemen, Strategi Bisnis, dan Kewirausahaan. 6(2):139-148.

Zhang, X., Jing, F., \& Yang, Y. (2012). How type of online commodities affect online impulse buying. Journal of Management Sciences, 25(3), 69-77. 